\title{
WestVirginiaUniversity
}

THE RESEARCH REPOSITORY @ WVU

Volume 56

Issue 2 Issues 2 \& 3

Article 2

June 1954

\section{The National Labor Relations Board}

Guy Farmer

National Labor Relations Board

Follow this and additional works at: https://researchrepository.wvu.edu/wvlr

Part of the Labor and Employment Law Commons

\section{Recommended Citation}

Guy Farmer, The National Labor Relations Board, 56 W. Va. L. Rev. (1954).

Available at: https://researchrepository.wvu.edu/wvlr/vol56/iss2/2

This Article is brought to you for free and open access by the WVU College of Law at The Research Repository @ WVU. It has been accepted for inclusion in West Virginia Law Review by an authorized editor of The Research Repository @ WVU. For more information, please contact ian.harmon@mail.wvu.edu. 


\section{WEST VIRG IN I A LAW REVIEW \\ Volume 56 \\ June 1954 \\ Number 2-3}

\section{THE NATIONAL LABOR RELATIONS BOARD*}

\section{GUY FARMER**}

I am happy to be here in Morgantown today and to speak before this forum. I have the honor to hold a B.A. degree from your College of Arts and Sciences and a law degree from your College of Law. Later in life my profession brought me back here many times and permitted me to see old friends and renew old and, to me, pleasant associations. I am proud of my long-time connection with this. University and with this town.

I must confess, however, that I never thought I would come back here in the capacity of a government official, and certainly I never dreamed that I would dare risk alienating those of my friends who are shocked at the thought of my becoming Chairman of the National Labor Relations Board. When I see the halfsuspecting, half-pitying look in the eyes of some of my oldest friends, I am tempted to claim that the whole thing is a case of mistaken identity. However, I cannot in good conscience take this easy out.

I confess! I am indeed the Chairman of the Labor Board.

This is a development, however, for which none in Morgantown or in the University need feel the slightest blame. My entry into the field of labor relations was purely accidental. I did not take a single course in labor relations or in labor law while a student here. Indeed, I think it is correct to say that in my time, not a single such course was given. In the College of Arts and Sciences, the course which I remember best was first-year economics. This course was taught by a wonderful old professor who viewed economics in the classic manner. I learned about the law of diminish-

* Address delivered at the Fourth Annual Labor Relations Conference at West Virginia University, April 10, 1954.

* Chairman of the National Labor Relations Board. 
ing returns, the law of supply and demand, and the theory of the business cycle. I also learned how the concept and practice of division of labor came into being and finally culminated in the industrial revolution. I must admit that I have only a fuzzy recollection of these things, but they were fascinating to me at the time. As I recall it, division of labor came about because a group of fishermen found that, instead of each one making his own fish hooks and fishing boats, and then going out and catching the fish, cleaning them, and taking them to market, it was more productive for some to make fish hooks, some to fish, some to clean fish, and others to take the fish to market. I have accepted the thesis that this is the way it really happened, but I recall quite vividly how it occurred to me at the time, that in this new found efficiency the fellow who had to do nothing but fish all the time got the best of the bargain!

During my student days at the College of Law, I was also taught well. How much I learned is a matter of debate and I will pass over that quickly.

In Law School, I took the usual courses in real property, torts, contracts, etc., but as I said before, no course in labor law, for none was given, and, it is anybody's guess whether I would have elected to take it even if it were.

The truth is that not much thought was given to labor or labor law by professors or students in my student days. I got my law degree in 1936, and actually that was just about the time when the labor organizations and labor law as we now know them were being born. The Wagner Act was passed in 1935 and held constitutional in 1937. The Wage and Hour Act was passed in 1938, and I believe the Norris-LaGuardia Act in 1932. That was the beginning of labor law in its present-day sense. Likewise, labor unions were weak and almost defenseless in the early thirties. It was not until these labor statutes were passed, and the power and prestige of the government was invoked to enforce the right of employees to organize and bargain collectively, that labor unions began to grow and gather strength.

I am pleased to see that the University has kept pace with these developments. There has been a course in labor law given in the Law School for some years, and in fact, I have had the privilege of helping to teach it to students who have shown themselves eager to learn about it. I am sure that the College of Commerce has courses in labor-management relations. And, of greater significance are these labor-management relations forums which 
have been conducted here for a number of years and have apparently become an institution. I congratulate the University on its awareness of the national significance of labor problems and its worth-while effort to aid in bringing about a clearer understanding of labor problems. It is in the establishment of better understanding between management and labor that is to be found the best hope of obtaining industrial peace.

It may be of some benefit to the group if I tell you something about the approach which I, as Chairman of the NLRB, take to the problems of administering the NLRA, the statute which concerns itself intimately with labor-management relations.

The National Labor Relations Board administers a controversial law, and it would indeed be strange if the Board were not a controversial agency. We continue to live in the hope that we may some day become less controversial than the law which we administer. Speaking solely for myself, I am even hopeful that there will eventually be general acceptance of the basic fairness of the Taft-Hartley law itself. I say this because I am convinced that it is essentially a fair and balanced law. In truth, I am thankful that $I$ live in a country which recognizes and protects the right of capital to invest and seek by foresight and ingenuity to make a reasonable profit, and the right of labor to organize and bargain collectively. The area in this world where free enterprise and free trade unionism can co-exist on a basis of approximate equality is not a great deal wider than the geographical boundaries of these United States. It would be well for those persons, representing either industry or labor, who strive by politics, by legislation, by administrative edict, or by sheer force, to over-extend their particular sphere of influence, to contemplate gravely whether they would have their own way today at the risk of destroying the basic freedom which we cherish most.

Capital and labor are not the only power and pressure groups in our democratic society, but they are certainly among the most vocal. The efficacy of democracy is that we deal with these contending forces, not by suppressing them in accordance with a master plan, but by recognizing and encouraging each of them to advance the interests of their own groups. It is the wisdom of democracy that we see these groups as what they are-special interests which have perfectly legitimate aims which nevertheless must be reconciled with, not elevated above, the welfare of the public at large. It is the continuing challenge of democracy to establish a balance of power among these forces, which frequently 
clash with one another, and to preserve them as separate parts of our society without allowing one or the other of them to become the whole. It is the paradox of history that wherever capital or labor has gained complete domination through control of the state, it has destroyed not only its counterpart, but has destroyed itself as well. If there is anyone who quarrels with this conclusion, I offer in evidence the pages of history.

Democracy does not exist in America by accident. Our forefathers fought to gain freedom, and we have fought again and again to preserve it. Americans have an undying passion for democracy. We are willing to fight for it, because we know by instinct that a man cannot live without dignity and self respect. Perhaps it is because we revere democracy so much that we have acquired the patience and the forbearance to make it succeed where more sophisticated societies have failed.

Thomas Jefferson, one of the most thoughful of our founding fathers, taught us that democracy thrives on freedom and that "the least government is the best government." This precept is no less valid today that it was in 1789 , although it is considerably more difficult to apply. I, for one, do not regard the Wagner Act and its younger brother, the Taft-Hartley Act, as violating this salutary principle of government. These statutes are not, as some vehemently assert, as incompatible as Cain and Abel. Nor do they infringe unduly on freedom of action. They are, in my opinion, the twin cornerstones of a free and democratic industrial society. The Act -which recognizes the freedom of workers to organize and at the same time curbs abuses by both employers and unions-would not have been regarded by Jefferson, if he were alive today, as an unwarranted exercise of governmental restraint. First, the Wagner Act in 1935, and then the Taft-Hartley Act in 1947, were enacted by Congress in response to widespread public recognition of a public need. It will some day be acknowledged by management that the Wagner Act, with its irritations, gave needed vigor and life to free enterprise, just as labor may eventually concede that the Taft-Hartley Act, with its restrictions, was necessary to insure the continuance of free trade unionism. The public should not be disillusioned because these two forces, management and labor, do not now see this quite so clearly as they might. Preoccupation with the immediate tends to obscure the ultimate; that is precisely why we have a representative government which is empowered to make and enforce laws. 
I would not have you think that I look upon legislation as an unmixed blessing, or as a panacea for all our ills. Far from it. Like Thomas Jefferson, I regard any new regulation with a measure of suspicion. There is no magic in a law. The legislature may solemnly declare that iron pyrites are pure nuggets, but they will still be "fool's gold". So, in the field of labor-management relations, the millennium is not to be found in the halls of Congress. I do not, of course, say that the Act cannot stand amendmentcertainly it is not perfect. I doubt that it will ever become so, for that is not the way of democracy. I have an idea, however, that most people are pretty well satisfied with the law as it now stands. The proposals for amendments seem to go in conflicting directions, which is not surprising, since they stem from opposing philosophies. This may suggest that the present law is a fairly reasonable compromise for everyone. Two oxen, pulling against one another, never pulled anybody's cart out of the mire.

When it is comprehended that the Act which we administer is a balanced law, the role of the Labor Board is more clearly disclosed. It is our job to give that law a balanced administration in keeping with the basic congressional purpose which it embodies. Any other approach, based on politics, bias or partisanship, would subvert the will of Congress and lead us along dark and treacherous paths.

There has been a great deal of curiosity and speculation about this new Board, and this is natural since this is the first time in the 18-year history of the agency that a majority of the Board, or indeed a single member has been appointed by a Republican President.

This is a fact which is no doubt of some interest to historians who delight in presenting routine facts with an entertaining twist. But, I wish to emphasize that the Labor Board should never be thought of by its own personnel or by the public as a political organization. Politics play a proper part in the enactment of laws, but politics have no place in their administration. Our job is to administer the law with scrupulous adherence to congressional intent. In performing this task, we must be constantly on guard against any temptation to interpret the law as we might like to see it written. We must resist any impulse to abuse our authority in order to obtain a particular result, however socially desirable it might appear to us to be. We must be objective and impersonal, and we must strive for clarity of vision so that we may read the law, not as we would like it to read, but as it is now written, not 
as we might wish it to be, but as it really is. I do not mean to suggest by this that we will follow a narrow, over-literal approach. I realize of course that the interpretation and application of a statute such as the labor law is not a purely mechanical exercise. It requires a certain minimum of intelligence, understanding and breadth of experience, even to read. But, we will strive to read the book which Congress wrote and not sneak off to bed with a copy of Grimms" "Fairy Tales".

Since the beginning of March, 1954 the Board has had, for the first time in six months, a full complement of five members. Despite all the talk about a split on the Board, it is well to remember that we continued to function during this interim period and issued hundreds of decisions, most of which were unanimous, and none of which were endorsed by less than a majority. I would venture to say that there cannot be found anywhere four lawycrs with reasonable intelligence and independence of judgment who could make a better record of basic agreement.

When the decisions of the full Board begin to emerge, they will be seized upon and scrutinized. I think it is safe to say that this critical examination will not always be conducted with a friendly tolerant gaze. However, I venture the guess that those who are looking for particular and recurring alignments will be largely disappointed. The members of this board are individuals with different backgrounds and refreshingly independent views. There are no factions on this Board-political or otherwise, and I hope that there will be none. Our decisions are made in meetings attended by the full Board, and only after views of every member are fully aired. We believe that, out of the crucible of free discus. sion, the truth has a better chance to emerge. We are adult enough to know that we are making decisions in a dynamic and difficult field, and we have enough humility to understand that even our best judgment, honestly arrived at, may be wrong. We accept as a precept the sage remark of Mr. Justice Holmes, who said, "Every" opinion tends to become a law", and thus we shed no tears if we end up in the minority. If we are forced to dissent, we take refuge in the conviction that, while outvoted, we are necessarily outclassed.

I said awhile ago that the sole task of the Board is to administer a law. We suffer under the handicap of having a sweeping generic title-The National Labor Relations Board-which suggests that we have our hand in all aspects of all labor disputes. Of course, you all realize that this is far from the truth. We do not formulate administration labor policy-that is the function of the President 
and the Secretary of Labor. We do not legislate, despite assertions to the contrary-that is the function of Congress. And, we do not mediate strikes and labor disputes. That is the function of the federal and state mediation services. We hold representation elections; we determine bargaining units; we decide unfair labor practice cases involving unions and employers-and that is all. I can assure you that it is also quite enough!

I have no doubt that I have disappointed some of you by not talking about some of our decisions. But, the difficulty is that it would be improper for me to discuss decisions which have not yet been issued, or, indeed, not even reached. And, it would be pointless to talk about decisions already issued, since they are available to all of you who are interested enough to read them. Consequently, in this area, I have no recourse but to take refuge in the Latin phrase, which is so familiar to lawyers, "res ipsa loquitur". Our decisions will have to speak for themselves.

I can, however, mention some of the issues with which this Board is faced and to which I hope we will provide some kind of an answer within the reasonably near future.

1. Communism.-The issue of Communism in labor unions. We know, as do all of you, that our national unions and federations have long been aware of the menace of Communism and have taken vigorous steps to weed out the Communists. The unions realize better than anyone else that the Communist goal and free trade unionism are as day is to night. In their endeavor to root out this evil, the unions are entitled to our wholehearted support. This Board, acting pursuant to the congressional intent embodied in the affidavit requirement of section $9(\mathrm{~h})$, has embarked upon a stern program of policing these filing requirements. This has involved us in several lawsuits with certain unions whose officers are alleged to be Communists, and indeed, in some cases, have been indicted, and in others convicted of filing false affidavits with this Board.

In this legal wrangle, we have lost some cases in the lower courts, but, recently, we won an important one which the union has appealed. Where we have lost, we have taken an appeal. We will not give up until we have exhausted all legal means of giving effect to the congressional intent. This Board will never use section $9(h)$ to harass legitimate unions, but we are determined to do everything within our proper authority to dislodge the Communist leech which has sought to embed itself in the body of labor and drain off its vigor and strength. 
2. Jurisdiction.-The Act is so written as to give the Board permissive jurisdiction which is as broad as the sweep of the commerce clause of the Constitution. From the beginning, however, the Board, with the sanction of the courts, has restricted its assertion of jurisdiction to cases which it felt had a sufficient impact on interstate commerce to justify national intervention. When the Board codified its jurisdictional plan in 1950, however, it was taking a first step in the jurisdictional field on a systematic basic, and, therefore, was properly cautious in drawing its jurisdictional lines. Experience has shown that the 1950 plan swept in many small, local businesses and endeavors which could not, on any reasonable basis, be said to have a substantial effect on the flow of interstate commerce. Thus, local retail stores, local garages, local restaurants, laundries and other essentially local concerns and their employees were swept up automatically and brought within the aegis of a national board which was established to handle cases of national import. Experience under this plan has disclosed its hidden defects, and it is now necessary to reappraise it and announce new standards. The Board is now engaged in this endeavor, and it is my earnest hope and expectation that a new and workable plan will soon be announced. We do not approach this problem with any idea of denying employers, employees, or unions the protection of the law. We are concerned only with pursuing a rule of reason in jurisdiction as in all other issues with which the Board must deal. Congress gave us great leeway, but expected that we would use our power cirsumspectly and with restraint. The imposition of reasonable restrictions on our jurisdiction is dictated by the administration's economy program, by the requirements of orderly admintration, and by plain commonsense. I sincerely hope and expect that our new plan will soon be ready for announcement.

By limiting my remarks to these, I do not mean to suggest that we do not have other problems. An agency which handled 14,000 labor disputes in 1953 learns to live with problems; life would be dull without them. Perhaps our greatest problem is not so clearly defined nor readily answered. That is the problem of gaining public acceptance of the Board as an institution. There is probably no agency which has been co consistently and bitterly attacked. The Board has in truth had a stormy history. I will not attempt to assess the validity of the attacks on the Board. I cannot defend any Communists who may have infiltrated it or the misguided zealots who sometimes brought it into bad repute. But I have said before, and I will say again that, on balance, the 
NLRB has, in the main, done a courageous and a worth-while job of enforcing an unpopular law, both in the Wagner Act days and under Taft-Hartley. I would not quarrel with those who say there is still room for improvement.

But, my chief concern is not with the past but the future. The keynote of the Board will be impartiality. We will be neither pro-union nor pro-employer, but pro-public, for after all, this lawlike all others, was passed in the public interest. This goal of even-handed administration which we have set for ourselves is not easy to accomplish, but there is no other worth pursuing. We recognize that some people will not believe that we are impartial, and, what is even more depressing, other people, in both management and labor, will not want us to be impartial. These people will want to use us as an instrument to further their own interests, and they will be impatient with our stubbornness. Therefore, we know that we must appeal to that segment of our citizens who understand and appreciate the necessity for impartial administration. If this Board acquires any kind of following, it will be among those public spirited persons who believe in a fair and impartial administration of the law.

In closing I would like to leave this final thought with you. You are primarily people who represent management or labor. You know the practical problems of labor relations. We as a Board cannot bring about successful labor relations and collective bargaining between an employer and the union representing his employees. Good labor relations and genuine collective bargaining cannot be legislated or imposed by administrative fiat. Employers and unions who wish to succeed in this difficult field must do so by honest self-analysis, by constant and diligent effort, and by displaying in their conduct towards one another the spirit of fair play and give and take attitude which are basic to any democratic society. The National Labor Relations Board bears about the same relation to the practice of collective bargaining as the domestic relations court bears to the institution of marriage. We try to pick up the pieces after the wreckage has occurred, hoping thus to aid in rehabilitating the marriage. But we cannot insure a happy married life. I wish to emphasize that there are no easy answers to labor-management problems, and, whatever laws may be on the books, and however fairly they may be enforced, in the end the employer and the union must come together on equal terms, and work out their own salvation. 